\title{
Pengaruh Strategi Inkuiri Terhadap Hasil Belajar Ditinjau Dari Perbedaan Motivasi Belajar IPA Kelas V SD
}

\author{
Dhia Suprianti ${ }^{1}$, Munzil $^{2}$, I Wayan Dasna ${ }^{3}$ \\ ${ }^{1}$ Pendidikan Dasar-Universitas Negeri Malang \\ ${ }^{2}$ Pendidikan Fisika-Universitas Negeri Malang \\ ${ }^{3}$ Pendidikan Kimia-Universitas Negeri Malang
}

\section{INFO ARTIKEI}

\section{Riwayat Artikel:}

Diterima: 05-11-2020

Disetujui: 14-12-2020

\section{Kata kunci: \\ inquiry strategy; motivation to learn, learning outcomes; strategi inkuiri; motivasi belajar; hasil belajar}

\author{
Alamat Korespondensi: \\ Dhia Suprianti \\ Pendidikan Dasar \\ Universitas Negeri Malang \\ Jalan Semarang 5 Malang \\ E-mail: dhiasuprianti@gmail.com
}

\section{ABSTRAK}

\begin{abstract}
This research was conducted with the aim of testing the influence of guided inkuiri strategies assisted by interactive multimedia and learning motivation on the learning outcomes of elementary school students. This research uses quasi experimental design. Research subjects of 60 elementary school students. The instruments used were questionnaires to measure the difference in student learning motivation with a reliability level of Croanbach's alpha 0.891 and a multiple choice assessment instrument with cronbach's alpha reliability level of 0.872 . The research data was analyzed using the two way ANOVA method. The results of this study (1) there is an influence of student learning outcomes in the experimental class that get the treatment of interactive multimedia-assisted inkuiri strategies with control classes that get conventional treatment, (2) there is an influence between students in the experimental class and controls that have excellent different learning motivation, and (3) there is an interaction between guided and conventional inkuiri strategies with differences in student learning motivation.
\end{abstract}

\begin{abstract}
Abstrak: Penelitian ini dilakukan dengan tujuan menguji pengaruh strategi inkuiri terbimbing berbantuan multimedia interaktif dan motivasi belajar terhadap hasil belajar siswa SD. Menggunakan desain quasi eksperimen. Subjek 60 siswa SD. Instrumen yang digunakan yaitu kuesioner untuk mengukur tingkat perbedaan motivasi belajar siswa dengan tingkat reliability croanbach's alpha 0,891 dan instrumen penilaian hasil belajar berupa pilihan ganda dengan tingkat reliability cronbach's alpha 0,872. Data penelitian dianalisis menggunakan metode two way ANOVA. Hasil penelitian ini (1) terdapat pengaruh hasil belajar siswa pada kelas eksperimen yang mendapatkan perlakuan strategi inkuiri terbimbing berbantuan multimedia interaktif dengan kelas kontrol mendapatkan perlakuan secara konvensional, (2) terdapat pengaruh antara siswa pada kelas eksperimen dan kontrol yang memiliki motivasi berbeda, dan (3) terdapat interaksi antara strategi inkuiri terbimbing dan konvensional dengan perbedaan motivasi belajar siswa.
\end{abstract}

Pembelajaran ilmu pengetahuan alam di sekolah dasar lebih mengutamakan aktivitas yang berpusat pada siswa dan mendukung siswa untuk lebih memahami konsep, prinsip, dan cara kerja yang sangat berkaitan degan konteks kehidupan siswa dan dapat menjawab rasa keingin tahuan siswa (Susiani, dkk., 2013). Siswa di tingkat dasar rasa ingin tahunya sangat besar, pendapat ini juga disampaikan oleh Singh, dkk (2017) bahwasannya belajar sains di sekolah dasar merupakan pembelajaran yang ideal untuk memenuhi rasa ingin tahu siswa tentang apa yang dipelajarinya. Sains dapat diartikan sebagai ilmu dalam suatu proses belajar siswa yang membahas tentang fakta di bumi atau alam yang dapat melatih keterampilan siswa untuk mencari tahu bagaimana ilmu pengetahuan tentang alam ditemukan (Nur, 2019).

Pembelajaran ilmu pengetahuan alam juga dapat memberikan kematangan berpikir dan mampu meningkatkan perkembangan intelektual. Sama halnya yang dengan pendapat Lamanauskas (2013) bahwasannya pembelajaran tentang "sains" di lingkungan sekolah memberikan kematangan berpikir bagi siswa dan tidak dapat dipisahkan dari kurikulum sekolah, sedangkan pendapat Puspitasari (2019) menyatakan bahwa ilmu pengetahaun alam dalam pembelajaran di sekolah mampu membentuk kepribadian dan meningkatkan perkembanagan intelektual siswa sekolah dasar dan menjadikannya sebagai salah satu pembelajaran yang memiliki arti penting pada perkembangan kognitif siswa. Pembelajaran di Indonesia menggunakan kurikulum 2013 yang dilaksanakan secara tematik dan terdapat beberapa muatan salah satu muatannya, yaitu Ilmu Pengetahuan Alam. 
Terdapat kesesuaian antara penerapan pendekatan saintifik muatan ilmu pengetahuan alam dengan karakteristik belajar tentang "sains" yaitu pada saat siswa belajar tentang IPA ketika siswa mencari tahu tentang alam sekitar secara sistematis dan logis sebagai bagian dari proses penemuan. Pendekatan saintifik merupakan terjemahan lain dari model pembelajaran kontruktivisme (Waseso, 2018). Proses pendekatan saintifik, yaitu mengamati, menanya, menalar, dan mencoba merupakan bagian dari teori pembelajaran kontruktivisme. Menurut Dasna (2015) menciptakan kelas yang kontruktivistik dapat dilakukan dengan cara menciptakan kondisi kelas yang dapat membangkitkan motivasi belajar siswa, mendorong kreativitas siswa, dan menumbuhkan sikap positif pada siswa. Kelas kontruktivistik dapat terwujud dengan didukung pemilihan rancangan strategi pembelajaran yang terorganisir dengan baik dalam melaksanakan kegiatan belajar mengajar untuk siswa.

Rancangan strategi pembelajaran tepat dengan memilih strategi mengajar yang membuat aktif siswanya dan berpusat pada siswa yaitu menggunakan strategi inkuiri, strategi inkuiri terbimbing dapat membentuk kondisi kelas yang kontruktivistik. Strategi inkuiri terbimbing sangat mudah dilaksanakan dan sangat cocok diterapkan untuk mengajak siswa berpikir ilmiah (Munzil, 2017). Siswa dapat melakukan tugasnya dalam pembelajaran seperti seorang ilmuan untuk mendapatkan pengetahuan yang baru dengan menggunakan strategi inkuiri terbimbing terutama untuk siswa sekolah dasar (Moore, dkk., 2013). Strategi inkuiri terbimbing merupakan kegiatan melakukan penyelidikan terhadap suatu masalah atau kasus dan memiliki langkah-langkah pembelajaran atau biasa disebut dengan sintak strategi inkuiri terbimbing.

Secara umum, strategi inkuiri terbimbing memiliki langkah, yaitu identifikasi masalah, siswa membuat rumusan masalah sendiri, menyusun jawaban sendiri, mengumpulkan fakta untuk dijadikan data, menguji benar tidaknya jawaban siswa, dan memguraikan kesimpulannya (Sanjaya, 2016). Strategi inkuiri terbimbing telah diyakini memiliki keunggulan, yaitu dapat meningkatkan pemahaman konseptual, keterampilan berpikir, meningkatkan hasil belajar dan memecahkan masalah (National Research Council 2000). Selain itu, strategi inkuiri terbimbing memiliki keunggulan dapat mengembangkan keterampilan proses pembelajaran ilmu pengetahuan alam, mengembangkan kreativitas, mendorong kemandirian, serta mengembangkan pengetahuan bersifat tentatif atau sementara (Bruce, dkk., 2015).

Strategi inkuiri terbimbing memperkuat pemahaman konseptual siswa yang memungkinkan siswa menemukan jawaban sendiri serta mampu membangun pemahaman diri lebih dalam dan mandiri (Laksana, dkk., 2019). Strategi inkuiri terbimbing lebih disarankan untuk digunakaan pada pembelajaran siswa sekolah dasar (Koksal, dkk., 2014) karena siswa sekolah dasar belum terbiasa menggunakan pendekatan kontruktivis, dimana dalam pembelajaran dengan menggunakan strategi inkuiri terbimbing guru berperan lebih banyak sebagai pembimbing siswa (Kirschner, dkk., 2006). Strategi inkuri terbimbing diterapkan di sekolah dasar dengan menggunakan pertanyaan-pertanyaan untuk memancing pengetahuan awal siswa (Prince, dkk., 2007) sehingga dapat membiasakan siswa untuk berpikir ilmiah (Dasna, dkk., 2013).

Strategi inkuri memiliki empat tingkatan level, yakni level 0, 1, 2 dan 3 (Fay, dkk., 2007). Strategi inkuiri terbimbing berada pada level 1 dan 2 (Munzil, 2017) level 1 memiliki ciri masalah dan guru yang menyiapkan dan memberikan prosedurnya, siswa melakukan interpretasi data sesuai yang diminta oleh guru, data yang diperoleh dari kegiatan percobaan yang ada pada lembar kerja siswa, sedangkan level 2 hanya masalah yang disajikan oleh guru siswa diberi kebebasan untuk menyelesaikan dan menginterpretasikan data yang didapat. Pada penelitian ini menggunakan strategi inkuiri level 1, strategi inkuiri terbimbing berada pada level 1 dan 2 (Munzil, 2017). Pelaksanaan pembelajaran dengan menggunakan strategi inkuiri terbimbing memiliki beberapa kekurangan.

Kekurangan dalam pembelajaran menggunakan strategi inkuiri terbimbing yaitu pada saat guru menyajikan materi pembelajaran hanya menggunakan teks bacaan akan kurang menarik perhatian siswa, untuk itu dibutuhkan media yang relevan yang dapat menarik perhatian siswa, begitu juga pada tahap menyajikan masalah pada siswa di masa pandemi maka dibutuhkan media berupa video untuk menyampaikan masalah dan petunjuk pelaksanaan kegiatan pembelajaran. Multimedia interaktif memiliki tampilan-tampilan menarik yang terdiri materi berupa teks, memiliki gambar yang relevan dengan materi, video, "sound" dan gambar bergerak (animasi) serta dilengkapi dengan lagu dan peta konsep yang dapat menarik perhatian siswa.

Multimedia interaktif memiliki karakter yang unik menurut (Darmawan, 2015) konten materi yang terdapat pada multimedia interaktif dalam bentuk visual, audiovisual yang beragam bentuknya sebagai sarana komuknikasi dengan siswa. Sejalan dengan pendapat (Zhang 2005) menyatakan bahwa pembelajaran berbasis multimedia interaktif menawarkan lebih banyak interaksi antara siswa dengan konten pembelajaran yang memanfaatkan kemajuan teknologi. Dalam proses belajar mengajar penggunaan multimedia interaktif akan sangat memberikan manfaat alasannya yaitu siswa dengan mudah menguasai materi dalam pembelajaran ilmu pengetahuan alam (Kasmui, 2014). Penggunaan strategi inkuiri terbimbing dibantu dengan multimedia interaktif sebagai inovasi pembelajaran semakin baik jika didukung adanya motivasi belajar siswa.

Motivasi belajar didefinisikan sebagai proses dimana aktivitas diarahkan pada tercapainya tujuan belajar, siswa akan terbangkitkan rasa percaya diri pada dirinya untuk mampu mendapatkan keberhasilan dalam mencapai hasil belajar (Cook, dkk., 2016). Motivasi belajar merupakan kekuatan pada siswa yang dapat menimbulkan kemauan yang kuat untuk melakukan kegiatan belajar (Suprihatin, 2015). Membangkitkan minat dan motivasi belajar siswa bukanlah hal yang mudah, guru sebagai profesi yang memiliki profesionalitas harus mampu menggali apa saja agar minat dan motivasi siswa dapat terbangkitkan ketika mengikuti kegiatan belajar mengajar (Azhar, dkk., 2017). 
Berdasarkan uraian di atas pembelajaran muatan ilmu pengetahuan alam dengan menggunakan strategi inkuri terbimbing berbantuan multimedia interaktif dengan perbedaan motivasi belajar siswa pada tingkat sangat baik, baik dan cukup baik berpotensi memiliki keunggulan dibanding strategi konvensional di SD kelas V. Dengan demikian, sangat relevan untuk dikaji pengaruh strategi inkuiri terbimbing berbantuan multimedia interaktif tema VIII muatan IPA tentang air dengan perbedaan motivasi belajar yang dimiliki siswa. Hal tersebut guna melihat respons ide untuk mengkaji penggunaan strategi inkuiri terbimbing berbantuan multimedia interaktif dengan tingkat motivasi belajar yang berbeda maka perlu tindakan suatu penelitian.

\section{METODE}

Jenis penelitian ini quasi eksperiment melibatkan dua kelompok belajar siswa. Data dianalisis menggunakan metode deskriptif statistic dan analisis multivariate yaitu Twoway ANOVA SPSS 22.0 for windows. Subjek yang dilibatkan seluruh siswa kelasVA 30 siswa (kelas ekperimen) dan kelasVB 30 siswa (kelas kontrol). Pada setiap kelompok belajar yaitu dua kelas sebagai subjek penelitian berdasarkan kesetaraan skor pretest. Satu kelas untuk strategi inkuiri terbimbing berbantuan multimedia interaktif dan satu kelas untuk strategi pembelajaran konvensional. Sampel diambil secara utuh pada dua kelas. Angket motivasi belajar dan alat penilaian tes hasil belajar siswa digunakan sebagai instrument penelitian. Variabel bebas yaitu strategi inkuiri terbimbing dan strategi konvensional, hasil belajar subjek penelitian sebagai varibel terikat dan variabel moderasinya yaitu motivasi belajar. Pengumpulan data melalui tes hasil belajar siswa yang sudah divalidasi empirik siswa dari sekolah lain, pada soal posttest diterima dan dapat digunakan karena setiap butir soal valid dan reliabel.

\section{HASIL}

Sebelum dilakukan uji independent t test dan uji two way ANOVA uji prasyarat terlebih dahulu dan hasil yang didapatkan memenuhi syarat untuk dilakukan uji independent $t$ test dan uji two way ANOVA.

Tabel 1. Rata-rata Hasil Siswa Berdasarkan Perbedaan Strategi dan Motivasi Belajar

\begin{tabular}{ccccccc}
\hline \multirow{2}{*}{ Motivasi Belajar } & \multicolumn{6}{c}{ Rata-rata Nilai Siswa } \\
\cline { 2 - 7 } & Pretest & Posttest & Selisih & Pretest & Posttest & Selisih \\
\hline Motivasi Tinggi & 65.93 & 88.21 & 22.28 & 65.00 & 73.27 & 8.27 \\
Sedang & 57.54 & 82.00 & 24.46 & 63.30 & 72.00 & 8.70 \\
Rendah & 47.00 & 74.33 & 27.33 & 59.67 & 67.00 & 7.33 \\
\hline Total & 60.40 & 84.13 & 23.74 & 62.83 & 70.97 & 8.14 \\
\hline
\end{tabular}

Berdasarkan paparan tabel 1 di atas kelas eksperimen (strategi inkuiri terbimbing menggunakan multimedia interaktif) mempunyai peningkatan rata-rata nilai paling tinggi pada motivasi belajar tinggi sebesar 88,21 dari 100. Dibandingkan pada kelas kontrol (strategi konvensional) dengan motivasi tinggi 73,27 dari 100. Rata-rata kelas pada kelas eksperimen 82,00 dan kelas kontrol yaitu 72,00 terlihat dari paparan data tabel 1. Nilai rata-rata kelas eksperimen dengan motivasi rendah sebesar 74,33 dan kelas kontrol dengan motivasi rendah sebesar 67,00.Kelas eksperimen yang mendapatkan perlakuan strategi inkuiri berbantuan multimedia interaktif memberikan pengaruh dan lebih efektif dan dapat diterapkan oleh guru di kelas. Dari paparan data tersebut menunjukkan bahwa strategi inkuiri terbimbing berbantuan multimedia interaktif dengan perbedaan tingkat motivasi belajar mempengaruhi hasil belajar siswa. Tabel 2 menunjukkan hasil analisis data anova dua jalur (two way ANOVA).

Tabel 2. Analisis Two way Anova Menggunakan SPSS 22.0

\begin{tabular}{lccccc}
\multicolumn{7}{c}{ Dependen Variable: } & Hasil Belajar & \\
\hline Source & Type III Sum of Squares & Df & Mean Square & F & Sig. \\
\hline Corrected Model & $3391.644^{\mathrm{a}}$ & 5 & 678.329 & 40.736 & .000 \\
Intercept & 266279.761 & 1 & 266279.761 & 15990.900 & .000 \\
Strategi & 1329.159 & 1 & 1329.159 & 79.820 & .000 \\
Motivasi & 684.223 & 2 & 342.112 & 20.545 & .000 \\
Strategi * Motivasi & 123.944 & 2 & 61.972 & 3.722 & .031 \\
Error & 899.206 & 54 & 16.652 & & \\
\hline Total & 365131.000 & 60 & & & \\
\hline Corrected Total & 4290.850 & 59 & &
\end{tabular}

a. $\quad R$ Squared $=.790$ (Adjusted $R$ Squared $=.771$ ) 
Uji hipotesis pertama dipaparkan pada tabel 2. Baris strategi pada tabel 2 nilai $F$-hitung=79,820, taraf signifikansi=0,000. Hasil F-hitung > F-tabel $(79,820>4,000)$ dan $n=60$, taraf signifikansi 0,05 (5\%) nilai $F$-Tabel yaitu 4,000. Dari data tersebut menyatakan bahwa terdapat pengaruh pada 'hasil belajar' dengan siswa strategi inkuiri terbimbing dibantu multimedia interaktif. Dimana $\mathrm{H}_{1}$ diterima dan Ho ditolak.

Hasil pengujian hipotesis kedua, hasil analisisnya ada perbedaan signifikan antara siswa pada kelompok eksperimen yang memiliki motivasi belajar sangat baik,baik,cukup baik terhadap kelompok kontrol yang memiliki motivasi belajar tinggi, sedang, dan rendah dengan nilai $F$-hitung $=20,545$ dan $F$-Tabel $=3,16$ dan signifinikan 0,000.

Hasil pengujian hipotesis ketiga, Hipotesis ketiga Ha menyatakan ada pengaruh interaksi antara strategi inkuiri dengan motivasi belajar (sangat baik, baik dan cukup baik) terhadap hasil belajar. Uji hipotesis ketiga menunjukkan adanya interaksi antara strategi belajar inkuiri berbantuan multimedia interaktif dan strategi belajar kelas kontrol (konvensional) pada motivasi belajar pada hasil belajar di dua kelompok. Tabel 2 merupakan hasil uji hipotesis ketiga adanya interaksi antara strategi belajar inkuiri dan konvensional dengan motivasi belajar terhadap hasil belajar siswa $F$ - hitung $=3,722$ dan $F$ - Tabel $=3,16$ maka $F$ Hitung > F-Tabel.

\section{PEMBAHASAN}

\section{Pengaruh Strategi terhadap Hasil Belajar Siswa}

Terdapat pengaruh yang signifikan pada hasil belajar siswa pada kelompok eksperimen perlakuan strategi inkuiri berbantuan multimedia interaksi dan kelompok kontrol strategi konvensional. Kelas eksperimen rata-rata 'hasil belajarnya lebih tinggi dibandingkan kelas kontrol. Kelompok eksperimen rata-rata skor lebih tinggi dibanding kelompok kontrol dengan nilai signifikan t-hitung>t-tabel dapat diartikan dan terdapat perbedaan antara keduanya (Khan, dkk., 2011) sedangkan hasil penelitian (Dasna, dkk., 2019) nilai rata-rata posttes kelompok inkuiri lebih baik dari kelompok pembelajaran lain. Hasil penelitian (Artayasa, dkk., 2018) terdapat pengaruh penerapan inkuiri terhadap meningkatnya pemahaman konsep sains siswa.

Pernyataan yang menjelaskan bahwa jawaban pada lembar kerja siswa pada kelompok eksperimen lebih baik dapat dapat dijelaskan dalam pelaksanaan pembelajaran dengan menggunakan langkah-langkah pada strategi inkuiri. Jawaban siswa kelompok eksperimen pada lembar kerja siswa lebih lengkap dibandingkan dengan jawaban siswa kelompok kontrol yang menjawab dengan jawaban singkat dan memberi alasan yang kurang tepat.

Melalui pembelajaran ikuiri siswa terlatih untuk lebih mandiri menemukan jawaban sendiri dengan tepat berdasarkan hasil percobaan dan dapat mengontruksi pengetahuannya dari proses yang dilakukan dalam pembelajaran. Pemahaman siswa tentang apakah air sungai memenuhi syarat air bersih secara fisik (bau warna dan rasa) dipahami dengan baik oleh siswa setelah siswa melakukan percobaan dalam pembelajaran yang menggunakan strategi inkuiri berbantuan multimedia interaktif, pada kelas eksperimen siswa memberikan jawaban tidak karena air sungai berbau busuk, berwarna keruh, dan rasanya pahit.

Jawaban siswa pada kelas control berbeda dengan kelas eksperimen, siswa memberi alasan tidak sesuai harapan dan jawaban singkat, siswa hanya menjawab "tidak" tanpa disertai alasannya hanya menyebutkan banyak yang tercemar dimana seharusnya siswa memberi alasan dengan menyebutkan air sungai tidak layak dikonsumsi karena berbau, berwarna keruh dan berasa. Dalam penelitian dilaksanakan dalam enam pembelajaran, pembelajaran pertama membahas tentang sumber air siswa membuat rumusan masalah dari kata kunci yaitu apa dampak negatif dari penggunaan air tanah? Apa perbedaan air tanah dengan air permukaan? Kemudian siswa membuat jawaban sementara pada lembar kerja siswa yaitu dampak negatif dari penggunaan air tanah yaitu di dalam tanah ada ruang kosong yang dapat merusak bangunan. Siswa menjelaskan perbedaan air tanah dan air permukaan yaitu pada air tanah letaknya berada didalam tanah sedangkan air permukaan ada dipermukaan dan dapat dilihat oleh mata. Selain jawaban tersebut ada siswa yang menjawab pengambilan air tanah yang terus menerus mengakibatkan air tanah akan habis. Strategi inkuiri dapat meningkatkan hasil belajar siswa karena siswa menjadi tertarik untuk mengikuti pembelajaran, dalam strategi inkuiri siswa diajak untuk melakukan percobaan.

Siswa melakukan percobaan sesuai petunjuk pada lembar kerja siswa, hasil percobaan yang didaapat siswa yaitu jika menggunakan batu kerikil maka air akan tetap tinggi permukaannya jika menggunakan batu bata maka permukaan airnya akan terlihat berkurang hal itu dikarenakan air meresap dipermukaan batu bata yang terbuat dari tanah. Pada lembar kegiatan siswa terdapat pertanyaan yang berbunyi apakah ada perbedaan perairan darat dan perairan laut? Jawaban siswa yaitu perairan darat yaitu air yang ada di tengah daratan contohnya sungai sedangkan perairan laut yaitu perairan yang berada lautan. Guru melakukan interaksi dengan siswa melalui broadcast masengger whatsapp, siswa menjawab pertanyaan guru tentang hasil percobaan yang telah dilakukan siswa contohnya pada pembelajaran 5 siswa melakukan percobaan tumbuhan membutuhkan air untuk tumbuh.

Pada percobaan tumbuhan membutuhkan air untuk tumbuh siswa menggunakan biji kacang hijau, siswa menyiapkan tiga gelas untuk diisi kapas, pada gelas 1 tanpa diberi air hanya diberi kapan dan kacang hijau diatasnya, Gelas B berisi kapas, kacang hijau dan sedikit air, sedangkan gelas $\mathrm{C}$ berisi kapas, kacang hijau dan air dalam jumlah yang lebih banyak. Kemudian guru melakukan tanya jawab dengan siswa, ada kah perbedaan gelas A, B, dan C? siswa menjawab ada, gelas A kacang hijaunya tidak tumbuh sama sekalai, gelas B tumbuh, tetapi tumbuhannya pendek, sedangkan gelas C kacang hujaiunya tumbuh lebih tinggi. Gurupun memberikan pertanyaan selanjutnya yaitu kira-kira penyebabnya apa ya gelas A tidak tumbuh? Siswa menjawab 
karena tidak ditambahkan air pada kapas semakin banyak air maka semakin cepat tumbuh kacang hijaunya. Guru menanyakan apa yang terjadi setelah air diberi tawas? Siswa menjawab airnya menjadi bening dan di bawah gelas ada lumpur yang mengendap. Adakah perubahan pada bau dan warna air setelah diberi tawas? Awalnya airnya keruh dan berbau setelah diberi tawas jadi bening dan tidak berbau lagi.

Dari beberapa jawaban siswa tersebut menunjukan bahwa dengan strategi inkuiri mampu membuat siswa menemukan jawabannya sendiri berdasarkan hasil percobaan yang siswa lakukan. Strategi pembelajaran inkuiri dengan berbantuan multimedia interaktif mampu meningkatkan pengetahuan siswa sendiri maupun bersama kelompoknya dengan bimbingan guru melalui daring. Hal tersebut menjadikan strategi pembelajaran inkuiri dengan berbantuan multimedia inkuiri baik diterapkan dalam pembelajaran secara tatap muka maupun secara daring. Sejalan dengan pendapat yang disampaikan oleh (Bruce, dkk., 2015) menyatakan bahwa strategi inkuiri melalui langkah-langkah kegiatan yang dilakukan dapat meningkatkan keterampilan dan kreativitas siswa serta mampu memacu siswa belajar mandiri dan aktif

Hasil belajar siswa dapat meningkat dengan strategi inkuiri dengan berbantuan multimedia interaktif karena (1) saat guru memberikan materi pembelajaran melalui video yang dikirim melalui pesan siaran pada whatsapp, guru memancing siswa memberikan pertanyaan-pertanyaan sederhana menuju pertanyaan kompleks, guru mulai mengonstruksi pemahaman siswa yang lebih kuat; (2) saat siswa dibagi menjadi kelompok melalui kelompok whatsapp untuk melakukan diskusi secara online, siswa dapat menemukan sendiri beberapa jawaban dan memahami lebih mendalam tentang materi yang sedang dipelajari melalui moda daring dan saling berbagi pengetahuan bersama dengan anggota kelompoknya; (3) penjelasan konsep yang guru berikan tidak hanya bersumber pada buku siswa saja, tetapi didukung dengan pengembangan materi dengan menyusun peta konsep terlebih dahulu, selanjutnya menentukan indikator dan tujuan pembelajaran, guru membuat detail materi yang akan diajarkan sesuai dengan pengembangan dari peta konsep dan dari berbagai sumber; (4) pemahaman siswa digali dan diperkuat dengan bantuan multimedia interaktif dimana pada multimedia interaktif tersebut terdapat beberapa fitur materi yang sedang dipelajari, lagu, game, dan peta konsep yang mudah dioperasikan, diingat, dipahami, dan menarik untuk siswa.

Dalam pembelajaran daring ini dimana guru tidak bertatap muka langsung seperti kegiatan belajar mengajar pada umumnya dengan siswa, pembelajaran pada kelompok kontrol tetap berjalan dengan lancar dan sesuai dengan harapan, siswa mengerjakan lembar kerja siswa yang memuat langkah-langkah inkuiri dapat meningkatkan keterampilan proses berpikir sains, kreatif (karena siswa memanfaatkan alat dan bahan yang ada di lingkungan sekitarnya), mendorong siswa untuk mandiri dengan mengikuti langkah-langkah yang telah tertuang pada lembar kerja siswa, sejalan dengan pendapat Joyce, dkk (1996) yang menyatakan tentang kelebihan dari strategi inkuiri yaitu dapat meningkatkan keterampilan berpikir siswa, mendorong siswa untuk lebih mandiri, mengembangkan kesadaran siswa tentang ilmu pengetahuan yang bersifat tentatif dan memaknai materi pembelajaran dengan lebih baik melalui pengalaman yang siswa temukan pada saat melakukan percobaan. Strategi inkuiri memiliki tingkat keberhasilan pada peningkatan "hasil belajar" lebih tinggi dibanding strategi konvensional (Pandey, dkk., 2011).

Hasil temuan penelitian, teori, dan hasil penelitian sebelumnya yang relevan sebagai berikut. Pertama, ada pengaruh hasil belajar siswa pada strategi inkuiri terbimbing berbantuan multimedia interaktif siswa yang menerima pembelajaran strategi konvensional. Kedua, strategi inkuiri lebih baik dalam meningkatkan kemandirian siswa dalam melakukan percobaan dibanding dengan pengajaran yang menggunakan strategi konvensional. Ketiga, siswa lebih antusias mengikuti kegiatan belajar mengajar strategi inkuiri terbimbing dibanding konvensional.

\section{Pengaruh Tingkat Motivasi Belajar Siswa terhadap Hasil Belajar Siswa}

Pengujian kedua memperlihatkan pengaruh signifikan antara motivasi awal siswa pada tingkat sangat baik, baik, dan cukup baik terhadap hasil belajar siswa. Hasil pengolahan data melalui analisis twoway ANOVA diketahui siswa dengan motivasi belajar tinggi kelompok yang menerapkan pembelajaran strategi inkuiri berbantuan multimedia interaktif lebih tinggi nilainya dari siswa motivasi tinggi yang menggunakan strategi konvensional.

Tingkat motivasi belajar awal siswa memiliki peranan penting bagi seorang siswa dan sebagai seorang guru menjaga agar motivasi siswa dengan baik menjadi suatu keharusan yaitu dengan melakukan pembelajaran yang bervariasi dan menarik bagi siswa termasuk menggunakan strategi inkuiri berbantuan multimedia interaktif ini dapat menjadi cara membelajarkan siswa yang dapat menaikan rerata 'hasil belajar' pada siswa tingkat motivasi tinggi. Guru memberikan reward kepada siswa agar siswa aktif dan termotivasi untuk terus belajar dengan baik. Motivasi belajar siswa dapat meningkatkan hasil belajar siswa dapat tercapai jika siswa memiliki perhatian, relevansi, kepercayaan, kepuasan dan adanya kemauan (Keller, 2016).

Siswa yang sangat termotivasi akan belajar dengan giat untuk mencapai tujuan, tetapi siswa yang tidak terlalu termotivasi akan menunda-nunda dan tujuan pembelajaran tidak penting bagi mereka (Keller, 2016). Agar siswa termotivasi untuk belajar peneliti menggunakan strategi inkuiri terbimbing. Proses pembelajaran diawali dengan siswa mengamati video dan membaca teks pada multimedia interaktif yang telah dirancang peneliti, kemudian siswa mengikuti petunjuk yang ada pada lembar kerja siswa, guru membimbing siswa melalui video dan video call pada kelompok kecil yang telah guru bentuk sebelumnya dengan menggunakan platform whatsapp. Dalam lembar kerja siswa terdapat petunjuk melakukan percobaan sesuai dengan materi belajar. 
Siswa melakukan percobaan dengan penuh semangat. Kategori perhatian, relevansi, kepercayaan, kepuasan serta kemauan dalam kegiatan belajar dalam penelitian ini terpenuhi. Ketika mengikuti pembelajaran ini siswa menunjukkan gairah minat dan rasa ingin tahu begitu besar, siswa aktif bertanya pada guru ketika melakukan kegiatan video call setelah siswa menyimak video dan membaca teks pada multimedia interaktif. Seluruh siswa menunjukan sikap yang konsisten menyelesaikan percobaan dari pembelajaran pertama sampai terakhir. Dari seluruh siswa di kelas eksperimen berhasil menyelesaikan percobaannya dengan baik, adapun halangan yang dihadapi siswa yaitu ketersediaan sarana dan prasarana di rumah, ada dua siswa yang melaporkan atau mengumpulkan pekerjaan tidak tepat waktu.

Siswa yang mengumpulkan hasil pekerjaan tidak tepat waktu dikarenakan ada kendala pada ketersediaan alat komunikasi, handpohone yang siswa gunakan untuk berkomunikasi masih digunakan oleh orangtuanya untuk bekerja sehingga siswa mengumpulkan pekerjaannya setelah orangtuanya pulang kerja akan tetapi siswa tetap menyelesaikan pembelajaran di pagi hari sesuai dengan jadwal yang guru berikan. Dua siswa tersebut tetap melakukan percobaan dan mengikuti petunjuk dari guru dengan bergabung bersama teman yang rumahnya berdekatan. Strategi inkuiri terbimbing dengan berbantuan multimedia interaktif dapat menciptakan perilaku belajar mandiri yang sangat diminati siswa.

Selain diminati siswa juga mampu menumbuhkan kemauan siswa untuk rajin belajar, meskipun kegiatan belajar dilakukan di rumah. Hal ini dapat dibuktikan dengan pembelajaran pertama sampai terakhir siswa dan orangtua proaktif dalam mempersiapkan peralatan yang dibutuhkan siswa untuk belajar dan melakukan percobaan sesuai dengan petunjuk pada lembar kerja siswa. Mengumpulkan tugas di hari yang sama dan memberikan respons positif dengan mengatakan bahwa kegiatan pembelajaran dan percobaan sangat menarik dan membuat siswa lebih mandiri.

\section{Pengaruh Interaksi Strategi Inkuiri Terbimbing berbantuan multimedia interaktif dan tingkat motivasi belajar siswa terhadap Hasil Belajar Siswa}

Terjadi interaksi inkuiri terbimbing berbantuan multimedia interaktif dengan perbedaan tingkat motivasi belajar awal siswa terhadap nilai hasil belajar. Interaksi ini dimaknai dengan menggunakan strategi inkuiri berbantuan multimedia interaktif akan berjalan baik bila siswa memiliki motivasi belajr tinggi dan tidak akan berpengaruh jika motivasi belajar siswa rendah. Pada tingkat motivasi belajar yang sangat baik pada kelompok eksperimen dengan strategi inkuiri berbantuan multimedia interaktif lebih tinggi hasil belajarnya dibandingkan pada siswa yang mendapatkan perlakuan pembelajaran strategi konvensional. Strategi inkuiri berbantuan multimedia interaktif dan perbedaan tingkat motivasi belajar awal sebelum diterapkan pembelajaran terhadap hasil belajar siswa. Pada tingkat motivasi belajar tinggi kelompok eksperimen terjadi peningkatan nilai siswa.

Pada kegiatan belajar dari rumah di masa pandemi, motivasi belajar yang ada pada diri siswa memiliki peranan penting, jika sebelum pandemi siswa bertatap muka dengan guru dan apabila mengalami kesulitan bisa langsung berinteraksi dengan guru di masa pandemi ini pembelajaran berjalan dengan baik dan tujuan pembelajaran dapat tercapai apabila didukung dengan adanya motivasi belajar yang tinggi pada siswa. Dengan motivasi belajar yang tinggi pada siswa maka ada dorongan atau kemauan pada siswa untuk melakukan pembelajaran dengan baik, meskipun tidak bertatap muka dengan guru.

Siswa di kelas eksperimen yang menggunakan strategi inkuiri terbimbing berbantuan multimedia interktif dengan tingkat motivasi tinggi memiliki rata-rata 'hasil belajar'lebih tinggi dibandingkan siswa motivasi tinggi strategi konvensional $(88,21>73,27)$. Siswa di kelas eksperimen yang menggunakan strategi inkuiri terbimbing berbantuan multimedia interaktif dengan tingkat motivasi sedang rata-rata 'hasil blajar siswa lebih tinggi dibanding siswa motivasi belajar sedang pada kelas konvensional $(82,00>72,00)$. Siswa di kelas eksperimen yang menggunakan strategi inkuiri terbimbing berbantuan multimedia interaktif dengan tingkat motivasi rendah rata-rata 'hasil belajar' lebih tinggi dibanding siswa dengan motivasi belajar di tingkat rendah pada kelas konvensional $(74,33>67,00)$.

Dari penjelasan di atas, temuan peneliti terkait penggunaan strategi inkuiri terbimbing pada masa pandemi sebagi berikut. Pertama, siswa yang berada dalam kelompok eksperimen menghasilkan nilai lebih tinggi dibanding kelompok kontrol dan didukung dengan motivasi belajar yang tinggi, artinya kedua variabel bebas saling terikat, nilai siswa meningkat jika menerapkan strategi inkuiri terbimbing didukung dengan adanya motivasi belajar tinggi. Kedua, motivasi belajar tinggi jika tidak disertai dengan strategi belajar yang tepat maka hasil belajar tidak lebih tinggi dari siswa di kelas yang menerapkan strategi inkuiri terbimbing. Ketiga, strategi inkuiri dapat dilaksanakan pada pembelajaran daring di masa pandemi di tingkat sekolah dasar dengan melakukan penyesuaian pada cara berkomunikasi dengan siswa yang tentunya berbeda dengan pembelajaran tatap muka pada umumnya.

\section{SIMPULAN}

Simpulan disusun dan dipaparkan berdasarkan hasil penelitian, dapat disampaikan berdasarkan fokus perencanaan, pelaksanaan dan penilaian pada strategi pembelajaran inkuiri dengan multimedia interaktif, yaitu ada pengaruh hasil belajar antara kelompok kontrol (strategi konvensional) dan eksperimen menerima perlakuan strategi pembelajaran inkuiri. Pertama, ada perbedaan yang signifikan pada nilai hasil belajar antara siswa yang memiliki motivasi belajar sangat baik, baik, dan cukup baik. 
Kedua, ada pengaruh interaksi antara strategi inkuiri terbimbing dengan motivasi belajar terhadap nilai (hasil belajar). Ketiga, ada pengaruh interaksi inkuiri terbimbing dengan motivasi siswa saat belajar terhadap hasil belajar.

Saran bagi semua pihak yang ada kaitannya dengan penggunaan hasil penelitian. Pertama, bagi sekolah untuk menjadi bahan menyusun dan merancang kegiatan belajar berpusat pada siswa, strategi inkuiri menggunakan multimedia interaktif dapat dilaksanakan dengan baik, tepat dan 'hasil belajar' yang didapatkan siswa lebih maksimal dibandingkan dengan menggunakan strategi konvensional. Diharapkan sekolah melaksanakan program-program sekolah yang dapat mendukung proses belajar berpusat pada siswa, yaitu strategi inkuiri dengan multimedia interaktif pada pembelajaran IPA. Kedua, bagi pendidik, dapat dijadikan pertimbangan bagi pendidik merancang dan mengembangkan strategi inkuiri terbimbing tidak hanya pada muatan IPA, tetapi juga pada muatan lainnya dengan menyesuaikan karakteristik muatan dan karakteristik siswa agar tujuan pembelajaran tercapai, pembelajaran menyenangkan bagi siswa, dan membangkitkan motivasi belajar siswa.

\section{DAFTAR RUJUKAN}

Artayasa, I. P., Susilo, H., Lestari, U., \& Indriwati, S. E. (2018). The effect of Three Levels of Inquiry on the Improvement of Science Concept Understanding of Elementary School Teacher Candidates. International Journal of Instruction, 11(2), $235-248$

Bruce, J., Weil, M., \& Calhoun, E. (2015). Models of Teaching $9^{\text {th }}$ Edition. Pearson.

Cook, D. A., \& Artino, A. R. (2016). Motivation to Learn: An Overview of Contemporary Theories. Medical Education.

Darmawan, D. (2015). Inovasi Pendidikan-Pendidikan Praktik Teknologi Multimedia dan Pembelajaran Online. Bandung: Remaja Rosda Karya.

Laksana, D. N. L., Degeng, I. N. S., \& Dasna, I. W. (2019). The Effects of Inquiry-Based Learning and Learning Styles on Primary School Students' Conceptual Understanding in Multimedia Learning Environment. Journal of Baltic Science Education, 18(1), 51-62.

Fauziah, A., Rosnaningsih, A., \& Azhar, S. (2017). Hubungan Antara Motivasi Belajar dengan Minat Belajar Siswa Kelas IV SDN Poris Gaga 05 Kota Tangerang. Jurnal JPSD (Jurnal Pendidikan Sekolah Dasar), 4(2), 47-53.

Fay, M. E.,. Grove, N. P., Towns, M. H., \& Bretz, S. L. (2007). A Rubric to Characterize Inquiry in the Undergraduate Chemistry Laboratory. Chemistry Education Research and Practice, 8(2), 212-219.

Fitriyati, I., \& Munzil. (2017). Penerapan Strategi Pembelajaran Inkuiri Terbimbing Berbantuan Media untuk Meningkatkan Keterampilan Berpikir Ilmiah Siswa pada Pembelajaran IPA SMP. Jurnal Penelitian Pendidikan IPA, 1(1), 1-6. http://dx.doi.org/10.26740/jppipa.v1n1.p1-6

Keller, J. M. (2016). Motivation, Learning, and Technology: Applying The ARCS-V Motivation Model. Participatory Educational Research.

Khan, M Saeed et al. (2011). Effect of Inquiry Method on Achievement of Students in Effect of Inquiry Method on Achievement of Students in Chemistry at Secondary Level. International Journal of Academic Research, 3(1), 955-959.

Kirschner, P. A., Sweller, J., \& Clark, R. E. (2006). Why Minimal Guidance During Instruction Does Not Work: An Analysis of the Failure of Constructivist, Discovery, Problem-Based, Experiential, and Inquiry-Based Teaching. Educational Psychologist, 41(2), 75-86.

Koksal, E. A., \& Berberoglu, G. (2014). The Effect of Guided-Inquiry Instruction on $6^{\text {th }}$ Grade Turkish Students' Achievement, Science Process Skills, and Attitudes Toward Science. International Journal of Science Education, 36(1), 66-78.

Laksana, D. N. L., Dasna, I. W., \& Degeng, I. N. S. (2019). The Effects of Inquiry-Based Learning and Learning Styles on Primary School Students' Conceptual Understanding in Multimedia Learning Environment. Journal of Baltic Science Education, 18(1), 51-62.

Lamanauskas, V. (2013). Natural Science Education Importance in Adolescence. Journal of Baltic Science Education, 12(4), 396-398.

Maikristina, N., Dasna, I. W., \& Sulistina, O. (2013). Pengaruh Penggunaan Model Pembelajaran Inkuiri Terbimbing terhadap Hasil Belajar dan Keterampilan Proses Sains Siswa Kelas XI IPA SMAN 3 Malang pada Materi Hidrolisis Garam. Skripsi tidak diterbitkan. Universitas Negeri Malang, Malang.

Moore, E. B., Herzog, T. A., \& Perkins, K. K. (2013). Interactive Simulations as Implicit Support for Guided-Inquiry. Chemistry Education Research and Practice, 14, 257-268.

Nur, H. (2019). Penerapan Metode Pembelajaran Penemuan Terbimbing dalam Meningkatkan Hasil Belajar IPA pada Siswa Kelas V. Cokroaminoto Journal of Primary Education, 2(2), 53-58.

Prince, M., \& Felder, R. (2007). The Many Faces of Inductive Teaching and Learning. Journal of College Science Teaching, $36(5), 14-20$.

Puspitasari, Y. (2019). Peningkatan Pemahaman Siswa Kelas VI Materi Sistem Peredaran Darah Manusia menggunakan Media Interaktif Tahun 2018/2019. Proceeding of Biology Education, 3(1), 84-93.

Sanjaya, W. (2016). Strategi Pembelajaran Berorientasi Standar Proses Pendidikan. Bandung: Kencana. 
1724 Jurnal Pendidikan, Vol. 5, No. 12, Bln Desember, Thn 2020, Hal 1717-1724

Suprihatin, S. (2015). Upaya Guru Dalam Meningkatkan Motivasi Belajar Siswa. PROMOSI (Jurnal Program Studi Pendidikan Ekonomi), 3(1), 73-82. http://dx.doi.org/10.24127/ja.v3i1.144

Zhang, D. (2005). Interactive Multimedia-Based E-Learning: A Study of Effectiveness. The American Journal of Distance Education, 19(3), 149-162. 